\title{
SPEECH ACT ANALYSIS OF IGBO UTTERANCES IN FUNERAL RITES
}

\author{
Martha Chidimma Egenti* \\ \& \\ Benjamin I. Mmadike* \\ http://dx.doi.org/10.4314/og.v12i 1.3
}

\section{Abstract}

This paper attempts to classify speech acts in Igbo funeral rites in some towns in Awka South and Aguata local government areas in Anambra State. Paying the last respect to the dead is a common practice in Africa. In Igbo land, it is obligatory to bury the dead following the funeral rites practised by the various communities. In a funeral, there are utterances addressed to God, to the deceased, to the relatives of the deceased and to in-laws, friends and well-wishers. These utterances are meant to soothe the feelings of the mourners, to show solidarity and condole with the bereaved by encouraging them, to pay the last respect to the deceased, to express appreciation for the legacies of the deceased and to offer prayers for the repose of his/her soul. This study examines these utterances as speech acts using Searle's (1976) classification of speech acts. The aim is to identify the most common utterance speech forms that are manifested and used in funeral rites. The data were collected from funeral rites held in Igbo speaking areas in Anambra State such as Awka, Amawbia, Uga and Nkpologwu by means of a digital tape recorder. The study reveals that the directive, expressive, representative/assertive, commissive and declarative speech acts are used in funeral rites, with the expressive speech act utterances having the highest percentage $(48.3 \%)$, followed by the directive and assertive (17.2\%) and the commissive (13.8\%). However, the declarative speech act is the least in our data $(3.5 \%)$. One could conclude from this that the expressive speech act is essentially used to condole with the bereaved.

\section{Introduction}

A Speech act refers to the use of language in context to perform an action. It involves the speaker and the force of his speech and the effect it has on the hearer which determines what the speech act has 
been able to achieve. In other words, a speech act is a communicative activity defined with reference to the intentions of the speaker while speaking and the effects achieved on the listener (Crystal, 1992).

Several works on speech acts in both spoken and written texts, especially in the English language, have been carried out by scholars. A number of applications of the speech act theory to email and web-genres/sources include Cohen, Carvelho and Mitchell (2004), Carvalho and Cohen (2005), and Jeong Lin and Lee (2009). The oral genre include Ajiboye (2012), Ik-Iloanusi (2014), Egenti and Okoye (2015). However, Quador and Riloff (2011) note that the application of the theory to spoken dialogue and written texts has not received adequate attention. A number of works using this theory have also been done in Igbo (Mbata 2013, Ik-Illoanusi 2014). As a result of the very few works done in this area in Igbo, this study is undertaken to fill the gap.

Sequel to the above, this study aims to identify and classify the utterance forms through which speech acts can be expressed in funeral rites using Searle's (1976) speech act classification. Since not any kind of utterance form is used in funeral rites to soothe the bereaved relatives, to show solidarity and elicit the same from the listeners, this study is geared towards identifying these utterances so as to fill the gap with regard to fewer researches that have been done in this regard. This study uses speech act classes such as directive, representative/assertive, commissive, expressive and declarative speech acts in categorizing the utterance forms. This is to ascertain and identify the frequency of occurrence of each of the speech acts as used in funeral ceremonies among the Igbo of the southeast Nigeria, precisely from two neighbouring towns in Awka South and Aguata in Anambra state viz: Awka and Amawbia; Uga and Nkpologwu. The effects of these speech acts on the hearers were also observed. A total number of fifty (50) utterance tokens were collected by means of a digital tape recorder, but a total number of twenty-nine (29) utterance tokens from both local government areas were transcribed, glossed and analyzed for this study. Some of the utterances have pragmatic comments about them. The utterances are 
then listed under their respective speech acts according to whom they are addressed to.

The rest of the paper is outlined as follow; section 2 reviews the related works on speech acts and funeral rites, while sections 3 and 4 constitute the analysis of the utterance forms from the funeral rites and concluding remarks respectively. All high tones are left unmarked, following Green and Igwe's (1963) tone marking convention.

\section{Review of Related Literature}

In this section, we shall review works that have adopted the speech act theory and also present a conceptual overview of funeral rites and the processes. Searle's speech act classification explained in the last section shall form the theoretical framework.

\subsection{An Overview of Funeral Rites}

Funeral is derived from Latin funus, funer -'funeral, death, corpse'. According to Oxford Dictionary, "It is a ceremony or service held shortly after a person's death, usually including the person's burial or cremation". A funeral rite (s) refers to the ceremony conducted at the time of a funeral, in which prayers are offered on behalf of the deceased as s/he is laid to rest.

Funeral rites are as old as the human race itself. As long as there is a beginning of life; there is also an end of life. Funeral rites commemorate the end of the life of a person. Capone (2010) \& Nodoushan (2013) cited in Sahoo (2014:44) explain what funeral rites entail. They assert that:

Funeral rites make us aware of the link between life and death as well as the meaning of our lives on earth. It also helps us to enlarge our individual existence. It demonstrates how to live a virtuous life to be prepared for death instead of being afraid of it. It also fulfils a social collective intentionality 
When someone dies, the deceased is usually buried according to the custom, tradition, belief, rituals and practices. This varies between cultures and between religious affiliations within the culture. It involves a complex of beliefs and practices, prayers and rituals used to remember the dead are usually conducted in honour of the dead. In explaining why funeral rituals are important, Wolfelt (2013), among other reasons, says that since a funeral ritual is a public, traditional and symbolic means of expressing our beliefs, thoughts and feelings about the death of a beloved one; funeral provides us with an accepted venue to express our painful feelings, it is a time during which sympathizers condone the bereaved through an open expression of sadness. The funeral invites us to focus on our past relationship with that one single person and to share those memories with others; it gives the mourners the opportunity to remember the person who died and provides opportunity for mourners to support the bereaved etc.

Funeral rites in some cultures like the Hindus are not performed for infants and children, unmarried people and, suicide victims (Sahoo, 2014). Ekwuru (2009) also notes that in Igboland, the nature and types of funeral rites depend mostly on the socioreligious status of the dead. As such, children, youths and adults have different funeral rituals. However, there are some processes and proceedings involved in burial and funeral rites. Shinno (1997:214) explains the series of ritual proceedings for the dead among the Lao in South Nyanza. According to him, these proceedings have been modified by modern inventions and Christianity. They range from death announcement, vigil (budho), to grave digging (kunyo), burial (iko), accompanying the spirit of the deceased to the former battleground (teroburu matin), shaving (liedo), mourners' departure for their houses (kee), serving a meal to the deceased and its family by married women (yaodhoot), serving a meal to the deceased and its family by married women (tedo), going to the former battleground with the spirit of the deceased (tero burumaduong'), visiting the widow's natal home (tero cholla), dividing articles left by the deceased (keyo nyinyo), remembrance (rapar), serving a meal to the family of the deceased by affines (budho). Shinno's study 
among other things reveals that Luo rituals for the dead provide the people with the occasion to express their feelings of pain and deep grief by bitterly crying and singing their own lamentations.

Eze (2010) also highlights the processes involved in burial and funeral rites in Onicha, Ebonyi State. They include the following; the preparations for burial, wake keep/lying in state, dressing of the corpse, digging of the grave, and other dimensions in burial and funeral rites such as burial/interment, immolation, market outing, funeral procession, shaving of hair etc. It should be noted that in some communities in Anambra state, wake-keep has been abolished. What is obtainable nowadays is a brief lying in state before the funeral service and interment. After the interment, other funeral ceremonies such as visits of age grades, in-laws, friends, well-wishers follow immediately. They usually present their gifts, sympathize with the bereaved and take their seats. The in-laws and other mourners are directed to the particular places where they would be entertained. During the different stages in the funeral proceedings, the mourners sympathize with the bereaved, the utterance forms produced at these various processes are regarded as speech acts in this study.

Following from the processes involved in funeral rites, this study therefore, is basically on the spontaneous utterance forms arising from the brief lying in state before the funeral service and the ceremonies, during and after the burial/interment.

\subsection{Theoretical framework}

The Speech Act Theory developed from Austin's (1962) work: How to do things with words forms the basis of this study. This idea was further developed by Searle (1969) who became one of the major proponents of the theory. According to Austin, a speaker utters a sentence to perform some acts which he calls speech acts. These acts are categorized into three. The locutionary act refers to uttering a sentence with certain sense and reference or linguistic meaning. The illocutionary act is an act of performing some action in saying something such as giving information, warning, issuing a threat, request etc, while the perlocutionary act refers to the effect of the 
utterance of the speaker on the hearer i.e., what the speaker is able to achieve by saying something such as convincing, persuading etc. Both Austin (1962) and Searle's (1969) speech act theory hinge upon and practically make reference to the illocutionary act. Austin also talks about the felicity conditions which specify the truth and falsity of an utterance; they are the conditions required for the utterances to take effect, but when the conditions are not met, the utterance becomes infelicitous. A performative utterance that works is said to be felicitous, while the one that does not 'work' is said to be infelicitous. Nodoushan (2013:84) notes that Searle (1969) also identifies four conditions or rules for the effective performance of a given speech act.

a. Propositional Content Rules: specify the kind of meaning expressed by the propositional part of an utterance (i.e., sense-reference meaning);

b. Preparatory Rules: delineate the conditions which are prerequisite to the performance of the speech act;

c. Sincerity Rules: outline the conditions which must obtain if the speech act is to be performed sincerely;

d. Essential Rules: specify what the speech act must conventionally count as.

Searle (1979) draws on these rules to distinguish different speech acts. In other words, the rules establish a system for the classification of speech acts. Searle (1979) uses them to propose five classes of speech acts:

1. Assertives: commit $\mathrm{S}$ (peaker) to the truth of some proposition;

2. Directives: count as attempts to bring about some effect through the action of $\mathrm{H}$ (earer);

3. Expressives: count as the expression of some psychological state;

4. Commissives: commit $\mathrm{S}$ to some future action; 
5. Declaratives: are speech acts whose "successful" performance brings about the correspondence between the propositional content and reality.

These classes are simply the various utterance forms in which speech acts can be expressed in conversational dialogue and communication. These speech acts are enunciated in Mey (2001:120-123) as follows:

- Representative/assertive speech act commits the speaker to the truth of what $\mathrm{s} / \mathrm{he}$ has said i.e. the expressed proposition. It is a representation of the speaker's belief or assertion of something or of the state of affairs in the world which is evaluated as true or false. The speaker may, through his/her utterance; assert, conclude, describe or suggest something. For example, one can utter the sentence, The earth is round as an instance of a representative speech act.

- Directive speech act occurs when the speaker attempts to get the hearer to do something as a response. It involves making a request, asking a question, issuing an invitation, or issuing an order/command. Examples include; Please cover the grave, Bring the corpse, Come and pay your last respect to the deceased or Have you seen the priest?

- Commissive speech act is an utterance form in which the speaker commits to a future course of action. This could be expressed as a warning, threat or promise. Quadir and Riloff (2011) assert that common commissive speech acts are promises and threats. Examples of this act include: We shall dismiss on time, and I may have to expose you if you don't retrace your steps.

- Expressive speech act occurs in conversation when a speaker expresses his/her psychological state which is demonstrated when the speaker appreciates or thanks, apologizes, complains, welcomes, condoles, or congratulates the listener. For instance, We thank you for your gifts and presence, Do accept our heartfelt condolences etc. 
- Declarative speech act brings about immediate change of status or condition to an object by virtue of the statement itself as soon as it is uttered. It involves excommunicating, declaring war, christening, firing from employment etc. It should be noted that following the felicity condition of the truth and falsity of an utterance, the speaker performing the declarative speech act must have a special institutional role in the context that qualifies him/her to make such a declaration and for the declaration to be considered appropriate. For instance, the example requires a Judge to make such declarations as;

You are hereby sentenced to life imprisonment, and I acquit you on all the charges etc.

The different classifications simply show the kinds of utterance forms used in speech acts to perform some actions. We shall in the next section discuss works of some authors that have adopted this theory in their study.

\subsection{Empirical Studies}

Salmani (2013:97-98) discusses the social semiotics of funerary rites in Iran by examining speech acts and a short account of pragmemes. $\mathrm{He}$ argues that funerary rites and rituals in Iran are a special kind of speech events with a socio-psychological rather than communicative function. He also classifies speech acts produced in funerary rites in Shitte into three classes of speech: (a) speech directed to Allah, (b) speech directed to the deceased, and (c) speech interacted between the grieved people and their visitors. He concludes that elements of funerary rites and rituals can function as frames that shape the structure of speech and help its interpretation. In brief, funerary speech aims at soothing the grieved and consolidating the social aspects of humanity. Also, Moyo (2013) analyses speech acts and non verbal communication modes that accompany Shona funeral rites in order to explain the nuances of meanings from these various utterances to find out how they help to shape Shona funeral. Moyo's findings, among other things, reveal that Shona funeral context is 
shaped by the interplay of particular speech acts and non verbal cues.

With regard to the Igbo language, there are a number of works that have been carried out using the speech act theory framework. However, the researchers could not find any work in funeral rites in Igbo using this theory. There are different types of utterance forms that are used in discourse in which context is important for their interpretation. A number of Igbo scholars have noted the role of context in the interpretation of some speech acts in Igbo. Mbata's (2013) study of speech acts used in traditional and Christian marriage rites reveals that context plays a very significant role especially in speech acts in Igbo traditional rites where indirect speech acts are mostly used, while direct speech acts are used for the Christian marriage rites. She, therefore, notes that speech acts in Igbo depend on the situation or circumstance surrounding them for their meaning to manifest. Her analysis was not purely based on the classification of speech acts, but on the illocutionary acts and the perlocutionary speech acts. Similarly, Ik-Iloanusi (2014) in her study of proverbs observes that proverbs in Igbo perform different acts depending on the context, since the meaning of proverbs is contextual. However, she classifies the proverbs into speech act classes which reveal the various functions of proverbs in resolving conflicts and disputes, advising, instigating war, warning etc. She also observes that a proverb might belong to different classes depending on the context of use. Egenti and Okoye (2015) also demonstrate that most proverbs used for conflict resolution and/or reconciling strained or broken relationships fall into Searle's speech act categories of representative/assertive, directive and expressive acts which are more common and are used in resolving discord and achieving peace. They also note that the commissive and declarative speech acts are not identified in the proverbs used.

The subsequent section will adopt these classifications namely: expressive, directive, representative/assertive, commissive and declarative speech acts in the analysis of our data by classifying the utterance forms in funeral rites through which speech acts can be expressed. Since, the various utterance forms have their 
performative functions during communication, we shall in the next section classify and categorize these utterance forms as speech acts.

\section{Data Presentation and Analysis}

In this section, we shall present and analyze samples of spontaneous utterance forms collected from the various funeral rites and classify them using Searle's (1976) speech act classification.

\subsection{Classification of the Utterances}

There are twenty-nine (29) relevant utterances transcribed for this study. The simple percentage method is used to calculate the number of occurrences which is shown in a table and also represented in a bar chart. In order to avoid unnecessary repetition, only one utterance from the different utterances of the same meaning in the data is used. This is because some of the meanings of these utterances are similar and fall under the same category. However, for the sake of clarity, utterance forms that have same meaning but fall under different speech classes are repeated. These utterances are grouped according to the speech act classes to which they belong and to whom they are addressed, with some pragmatic comments in parenthesis as shown below:-

\subsubsection{Class I: Expressive}

\section{Utterances addressed to God}

1) Ànyị nà-ekène Chukwu màkà ezi ndụ nwanne ānȳ̄ bìrì n'ụ̂wa.

1PL PROG-thank God because good life brother 3-PL live-rVpst in world

'We thank God for the exemplary life of our departed brother.'

(This utterance is addressed to God in appreciation to Him for the life and times of the deceased.)

2) Ànyị nà-ekèle Chukwu màkà ife ọma o jìrì chọọ

1PL PROG-thank God for thing good 3SG hold-rV endow/bestow with 
nwannē ānȳ̄ mmā

brother 1PL.Poss good

'We appreciate God for the blessings He bestowed on our brother while on earth.'

\section{Utterances addressed to the relatives of the deceased}

3) Jìde obì gị akā, kasìe ōnwē gị obì. Hold heart 2SG Poss. hand, console self 2.SG heart 'Take heart and console yourself.'

(This utterance is addressed to the relatives of the bereaved to encourage them to be strong.)

4) Anyi bịarà kà ànyị sòro ụnụ bee akwā 1PL come rVpst that 1PL follow 2PL cry cry

'We have come to share in your sorrows'

5) Ǹdonụ̀!

IMP. Sorry you

'Accept our sympathy'

(This act is used here to express sympathy to the bereaved)

6) Ànyị sịị kà ànyị bịa kasìe gi obì

1.PL say-rVpst that 1PL come console 2SG heart

'We are here to console you'

7) Ogè ị nà ètinye ajā n'ịnị Màma, $i$ tìrì mkpu:

Time 2SG PROG put in sand into grave Mama, 2SG shout-rV:

"Ọ gw g̣̣sīgō"; $\quad \mathrm{m} \quad$ ch gwụsịbèghì.

"3SG finish.PERF"; ISG want to-tell 3SG that 3SG finish.PERF.NEG.

'When you were putting sand in Mama's grave, you exclaimed: "it is over"; I want to tell you that it is not all over.'

(Here, the speaker with words of consolation encourages the bereaved relatives to take heart and not to be despondent.) 
8) Ọ bụrụ nà nwannē ānỵ̣̄ bìri ndụ̀ ya ộụ̄mā,

3SG be-pst that sister 1PL.POSS live life 3SG.POSS well,

kèdụ ihe anyị jì èbe akwā?

What thing 1PL hold cry cry?

'If our sister/brother lived a good life, then why are we crying?'

(The speaker addresses the bereaved relatives with words of consolation to encourage them not to continue mourning as those who do not have faith in God.)

9) Ànyị jì anya mmịị̄ sị kà ànyị kèlee ụnụ... 1PL hold eye water say let 1PL greet 2PL...

'With deep sympathy, we wish to commiserate with you...' (Here, the mourners visit the bereaved to express their heartfelt condolences.)

\section{Utterances addressed to inlaws, friends and well wishers}

10) Ànyị nà-ekène ụnụ, wèe na-àsị kà $\quad$ ọ dịị ụnụ mmā ka ụnụ

1PL PROG-thank 2PL, then PROG-say that 3SG be-rVpst 2PL good because 2PL

sìrì bịa nọ̀nyere anyị

come from stay-rV APPL 1PL

'We thank and appreciate you and wish you well for your presence and support'

(Here, the speaker (one of the mourners and the spokesperson for the deceased) while addressing the inlaws, friends and well wishers expresses gratitude to all the wellwishers who have come from far and near to commiserate with them.) 
Ogirisi: a new journal of african studies vol 122016

11) Ànyị nà-àsị ụnù ǹnọ, bụ ndi bịāāā ị nọnyèrè ànyị

1PL PROG-say 2PL welcome, who all come-rVpst INF stay-rV APPL. 1SG

'We welcome all those who have come to be with us'

(The speaker in addressing the inlaws, friends and well wishers expresses his gratitude to their guests and welcomes them for attending the funeral ceremony.)

12) Ànyị nà-ekène ndi gwūrū inì mà kpochikwaa yā 1PL PROG-thank all dig-rVpst grave and cover-PERF 3SG it

'We thank those who dug and covered the grave'

13) Ndi ogọ̀, ànyị nà-ekèle ụnụ̆; ndi na-alụ nwa anyi.

People in-laws, 1PL PROG-thank 2PL; people PROGmarry child 1PL.Poss

'Our in-laws, we thank you.'

\section{Utterance addressed to the Deceased}

14) Onye ijè ǹnọ.

Person movement welcome.

'Welcome sojourner'

(The speaker announces the arrival of the corpse to his/her abode. This utterance is addressed to the deceased to welcome him/her back to his abode where $\mathrm{h} / \mathrm{she}$ would be laid to rest. It also arouses different emotions from the mourners such as pity, pain, praise, hope etc.)

The expressive speech acts are made during visits by age grades, inlaws, friends, well-wishers; and while presenting their gifts, they sympathize with the bereaved. A relative of the bereaved in response expresses gratitude for their presence. In other words, the speech act under this class simply shows appreciation. The speaker (relative of the bereaved) welcomes the well-wishers and expresses his gratitude to God and to all the well-wishers who have witnessed the funeral ceremony. This speech act is used to show an outpouring of 
emotion. It also portrays the psychological state of the bereaved family and the mourners.

\subsubsection{Class II: Directive}

\section{Utterances addressed to God}

15) Ànyị nà-àyọ Chukwu kà o o nabàta mkpuru obì ya na ndokwa.

1PL PROG-beg God that $3 \mathrm{SG}$ receive piece heart 3SG in peace

'We pray God to receive his/her soul in peace.'

\section{Utterances addressed to the relatives of the deceased}

16) Pụtanụ n’ọgbọ òzìgbo òzìgbo

Come-out-2PL in open quick quick

'Come out to the funeral arena immediately.'

(This is a speech act addressed to the bereaved relatives to come and perform some functions in which they are cheered up by showering them with some gift items. As such they are encouraged to be strong.)

17)

18) Jèenụ sàa nwannē ụụu akwà

Go-2PL cover brother 2PL.Poss cloth

'Go and present your wrapper to the deceased'

(The speech act is addressed to the relatives of the deceased who were asked to go and pay their respect to the deceased by placing a wrapper beside him/her. It is usually the case that these wrappers come as gift items to the bereaved family to encourage them)

19) Ụnụ mara ezi ihē nnà ụnū nà-ème m̀gbè ọ nọ ndụ̀, bikō kà ụnụ

2PL know good thing father 2PL PROG.do when 3SG stay life, please let 2PL

jisie ikē na-èmenụ ya.

With strength PROG-do-2SG. 
'We pray and enjoin you to continue with the footsteps of your late father'

(Here, the speaker advises the bereaved family to continue with the footsteps of their late father. It is a directive speech act because the speaker expects the hearers to do something so as to the keep the ideals of the deceased alive.)

\section{Utterance addressed to the Deceased}

20) Làà n'ùdó, bikò echèzọ̀kwànà ànyị

Go in peace, please NEG.forget 1PL

'Go in peace, please do not forget us'

The directive speech act gets the hearers to do something as a response. The speaker either requests, pleads, asks, advises, invites, permits, and prays etc., that the bereaved relatives or all those that are involved in one way or another in the funeral ceremony to come and perform the funeral rites. When it is addressed to God, it is a request and a prayer to receive the soul of the deceased in His paradise.

\subsubsection{Class III: Representative/Assertive} Utterance(s) addressed to God

21) ...Kà mkpụrụ obì nwannē ndokwa.

...let piece heart brother/sister 1PL rest in peace '...May the soul of our brother/sister rest in peace.'

\section{Utterances addressed to the Deceased}

22) Nòdu mmā, agụ nwokē

Stay well, lion man

'Rest in peace, strong man'

(The speaker uses 'Strong man' metaphorically in this utterance to testify that the deceased was energetic and full of strength while he was alive.)

23) Ừwa ọzọ̄ m gà-abịa, ị gà bụ nwannē m World another 1SG FUT-come, 3SG fut.be sibling 1SG.Poss 
'In my life hereafter, you will still be my brother'

24) Eziokwū àlaa!

Truth go.PERF!

'Truth is no more!'

(This utterance is addressed to the deceased while putting sand in the grave to affirm that the deceased was a man of high integrity who stood for truth and justice. 'Truth' is used as a virtue which the deceased stood for. The speaker in this utterance states a fact which the deceased stood for with the belief that the deceased lived an exemplary life)

25) Ezinnē $m, \quad$ jeè n'ùdo

Good mother 1SG.Poss, go in peace

'My dear, go in peace'

(This act is used to conclude and bid farewell to the deceased when the body is interred and the grave is filled with earth.)

The speech act used here simply represents the speaker's belief or assertions of something or of the state of affairs in the world which is evaluated as true or false. Through his/her statement therefore, the speaker is confident that the soul of the deceased will rest in peace.

\subsubsection{Class IV: Commissive}

\section{Utterances addressed to the deceased}

26) Ànyị gà àfụkwa ọ̀zọ. kà e mesịa 1PL fut-see again. Let it be later

'We shall meet again: Bye.'

(This speech act is addressed to the deceased with the hope that both the living and the dead will meet in the hereafter. That is to say, the speaker expresses hope that $\mathrm{s} / \mathrm{he}$ will meet the deceased again.)

27) Làa ǹkè ọm ; ànyị nà-àbịa.

Go one good; 1PL PROG.ptcpl. come

Go in peace, we are coming.'

(This speech act is addressed to the deceased with a promise that the speaker will meet the deceased again hereafter.) 
28) Ànyị gà-eleta Màma ānỵ̣̄ òtù $\quad$ i $\quad$ sìrì leta

1PL fut-look after Mama 1PL.Poss the way 3SG from look after

yā m̀ngbè I nọ ndụ

3SG when 3SG stay alive

'We will take care of Mama as you did when you were alive'

29) Ànyị agāghī echèzọ ezi ndụ I bìrì n'ùwà

1PL NEG FUT forget good life 3SG live-rVpst on earth

'We will not forget the good life you lived while on earth' (This act is a kind of promise by the bereaved to the deceased to follow the example the deceased has left behind).

\subsubsection{Class V: Declarative}

\section{Utterance(s) addressed to the deceased}

29) Eziokwū àlaa!

Truth go.PERF!

'Truth is no more!'

(This is a declaration of truth by the speaker who has fulfilled the propositional content, preparatory and sincerity conditions. Hence, the speaker is one of the siblings of the deceased who knows the deceased very well and as such qualifies him to make such a declaration. He uses 'truth' here to show that the deceased stood for truth and justice while he was alive. It should be noted that this example differs pragmatically in meaning from e.g (23) as there are necessary conditions to be fulfilled for the declaration to be valid which the speaker fulfilled.)

The results of the various speech act sentences are shown in a table and also summarized in a bar chart below: 
Table 1: Shows the frequency and percentage of the speech act class

\begin{tabular}{llcc}
\hline No. & Speech Act Class & $\begin{array}{c}\text { Number of } \\
\text { Utterances }\end{array}$ & $\begin{array}{c}\text { Percentage } \\
(\%)\end{array}$ \\
\hline 1 & Expressive & 14 & 48.3 \\
2 & Directive & 5 & 17.2 \\
3 & Assertive & 5 & 17.2 \\
4 & Commissive & 4 & 13.8 \\
5 & Declarative & 1 & 3.5 \\
\hline & TOTAL & 29 & 100
\end{tabular}

In the above table, the simple percentage is used to calculate the number of speech act classes divided by the total number of utterances.

The results of the various speech act utterances are summarized in the chart below:

Figure 1: shows the frequency of occurrence chart of speech acts

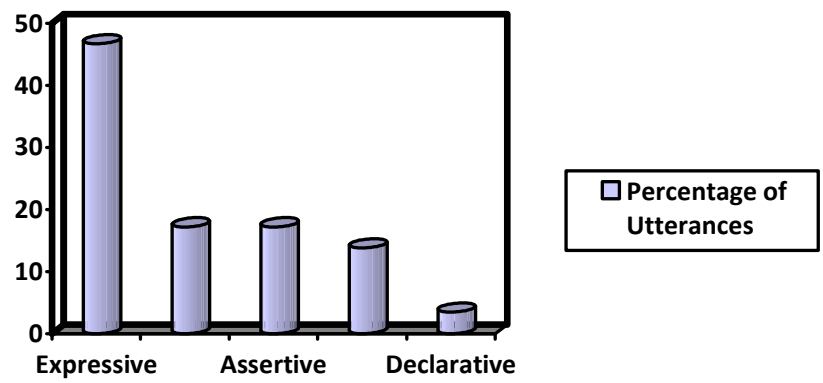

The above figure summarizes the frequency of occurrence of the different speech act utterances. The percentage differences among the speech acts are summarized as follows. The commissive and declarative speech act utterances have the lowest percentage of $13.8 \%$ and $3.5 \%$ each, followed by the directive and the assertive with both having $17.2 \%$. The expressive speech act has the highest percentage of $48.3 \%$. Our data therefore reveals that the expressive 
speech act is mostly used in funeral rites, while the commisive is the lowest used speech acts. The declarative speech class is the least in our data with $3.5 \%$.

In general, the speech acts are grouped into four; utterance(s) addressed to God as shown above in the various speech act classes (see e.g: $1,2,15, \& 20$ ); those addressed to the deceased (see e.g: 14, 19, 21, 22, 23, 24, 25, 26, 27, 28, \& 29); those addressed to the relatives of the deceased (see e.g: 3, 4, 5, 6, 7, 8, 9, $16,17 \& 18$ ); and those addressed to inlaws, friends and well wishers (see e.g: 10, 11, 12, \&13).

\section{Summary and Conclusion}

The study is based on Searle's (1976) speech act classification. The speech acts used in this study consist of twenty-nine sentence tokens. They were used to examine the frequency of occurrences of each of the individual speech acts used in funeral ceremonies among the Igbo, especially within the southeast of Nigeria, precisely in Awka South and Aguata LGA.

The study has revealed that the expressive speech act has the highest frequency of occurrence with $48.3 \%$, followed by the directive and assertive, which has both $17.2 \%$ each, while the commissive speech acts has $13.8 \%$. The declarative speech act has the least with $3.5 \%$. This leads to the conclusion that based on our data, we can infer that the expressive speech act is essentially used to condole with the bereaved.

*Egenti, Martha Chidimma is a Lecturer in the Department of Linguistics, Nnamdi Azikiwe University, Awka;

*Benjamin I. Mmadike is an Associate Professor in the Department of Linguistics, Nnamdi Azikiwe University, Awka. 


\section{References}

Ajiboye, Emuobonuvie. M. 2012. Proverbs and the Management of Conflicts in Oum. Ndimele (Ed.), Language, Interactive and Communication in a dynamic World. A festschrift for Chinyere Ohiri - Aniche, Vol. 9; 305-317.

Austin, J. L. 1962. How to do things with words. London: Clarendon Press.

Capone, A. 2010. On Pragmemes again: Dealing with death. La Linguistique. (46). 3-21.

Cavalho, Vitor R. \& Cohen William W. 2005. On the collective classification of email "speech acts". In SLGIR '05: Proceedings of the $28^{\text {th }}$ annual international ACM SIGIR conference on Research and development in information retrieval. Pp 345-352. New York, USA: ACM Press.

Cohen, William W., Carvalho, Vitor R., \& Mitchell, Tom M.2004. Learning to classify email into "speech acts". In EMNLP, 309-316. ACL.

Crystal, David. 1992. A dictionary of linguistics and phonetics $\left(3^{\text {rd }}\right.$ ed.). London: Blackwell.

Egenti, Martha. C. \& Okoye Adaobi. N. 2014. On the Role of Igbo Proverbs in Crisis management and Reconciliation being a paper presented at the Ist International Conference on Global Reconciliation in the $21^{\text {st }}$ century. Anambra State University, Igbariam Campus, $25^{\text {th }}-27^{\text {th }}$ September, 2014.

Ekwuru, Emeka G. 2009. Igbo Cosmology: the ontogeny and hermeneutics of Igbo sculpture. Studies in African Ethnoaesthetics. Owerri: Living Flame Resources.

Eze, Okorie N. The Socio-Economic and religious implications of burial and funeral rites in Onicha Ebonyi State, Nigeria. A Master thesis submitted to the Department of Religion and Human Relation, Nnamdi Azikiwe University, Awka. Retrieved from

www.naulibrary.org/dglibrary/admin/book_directory/thesis/10255.p df (10th September, 2015.) 
Green, M. M. \& Igwe, G. E. 1963. A Descriptive grammar of Igbo. London: Oxford University Press.

Ik - Iloanusi, Adaobi . 2014. Proverbs - A Speech Act Analysis. An unpublished Master's thesis submitted to the Department of Linguistics. Nnamdi Azikiwe University, Awka.

Jeong Minwoo, Lin Chin-Yew, \& Lee Geunbae G. 2009. Semisupervised speech act recognition in emails and forums. In Proceedings of the 2009 Conference on Empirical Methods in Natural Language Processing: Vol 3, EMNLP: 12501259, Stroudsburg: USA.

Levinson, Stephen C. 1983. Pragmatics. Cambridge: Cambridge University Press.

Mbata, Carolyn O. 2013. Analysis of speech acts in Igbo: A study of traditional and Christian marriage rites. A PhD Dissertation submitted to the Department of Igbo, African and Asian Studies, Nnamdi Azikiwe University, Awka.

Mey, Jacob L. 2001. $2^{\text {nd }}$ edn. Pragmatics: An introduction, London: Blackwell Publishing Co.

Moyo, Jabulani. 2013. The Interface of verbal and non verbal communication at Shona funeral milieu: sociolinguistic implications. International Journal of Humanities and Social Science Invention. 2 (9). 5-15. (www.ijhssiorg).

Nwachukwu, Agbada J.O.J . 2002. The Igbo Proverb: A study of its context, performance and functions. Enugu: John Jacobs Publishers.

Online Oxford Dictionary. Retrieved: www.oxforddictionary.com/definition/english/funeral. 10/9/15.

Quadir, Ashequl \& Riloff, Ellen. 2011. Classifying Sentences as Speech Acts in Message Board Posts. In Proceedings of 2011 Conference on Empirical Methods in Natural Language Processing EMNLP, USA 
Egenti \& Mmadike: Speech Act Analysis of Utterances in Funeral Rites

Noduoushan, Salami M. S. 2013. The Social Semiotics of Funerary Rites in Iran. International Journal of Language Studies, 7(1), 79-102.

Sahoo, Kalyanamalini. 2014. Rituals of death in Odisha: Hindus religious beliefs and social-cultural practices. International Journal of Language Studies. 8 (4). 29-48.

Searle, John. R. 1976. A classification of illocutionary acts. Language in Society, 5 (1). 1-23.

Searle, John. R. 1969. Speech Acts. An Essay in the Philosophy of language. Cambridge: Cambridge University Press.

Shinno, Wakana .1997. Death and Rituals among the Luo in South Nyanza. African Study Monographs. 18 (3, 4). 213-228.

Wolfelt, Alan. D. 2013. Why is the funeral Ritual Important? Family Therapy Magazine. Centre for loss and life transition. Retrieved from www.aamft.org/funeralritual.pdf on 10/9/15 